\title{
ANALISIS PELAKSANAAN KEWAJIBAN ATAS PAJAK PENGHASILAN PASAL 21 PADA RUMAH SAKIT X DI KLATEN-JAWA TENGAH
}

\author{
Nila Nurma Ningsih, Diska Arliena Hafni*
}

\begin{abstract}
ABSTRAK
Tujuan penelitian ini untuk mengananalisis pelaksanaan kewajiban Rumah Sakit X di Klaten atas pajak penghasilan Pasal 21. Penelitian ini menggunakan metode penelitian kualitatif dengan menggunakan pendekatan deskriptif. Data yang digunakan yaitu data primer dan data sekunder. Pengumpulan data dilakukan dengan cara observasi, wawancara dan dokumentasi. Teknik analisis data menggunakan analisis deskriptif dan analisis komparatif. Hasil dari penelitian ini menunjukkan bahwa selama tahun 2017 sampai dengan 2019 Rumah Sakit X dalam melaksanakan kewajiban atas pajak penghasilan pasal 21 dilakukan dengan cukup baik, meskipun dalam beberapa hal masih terdapat kesalahan. Berdasakan aktivitas perhitungan dan pemotongan $\mathrm{PPh} 21$, Rumah Sakit X masih belum sesuai dengan undang-undang perpajakan. Berbeda dengan perhitungan dan pemotongan pajak $\mathrm{PPh} 21$, aktivitas penyetoran dan pelaporan pajak Rumah Sakit X selama tahun 2017 sampai dengan 2019 sudah melaksanakan kewajibannya dengan tepat waktu dan sesuai aturan atau undang-undang yang berlaku.
\end{abstract}

Revised:

October 3, 2021

Accepted:

October 9, 2021

Published:

October 10, 2021

\section{Citation:}

Ningsih, N. N., \& Hafni, D.

A., (2021). Analisis

Pelaksanaan Kewajiban Atas

Pajak Penghasilan Pasal 21

Pada Rumah Sakit X Di

Klaten-Jawa Tengah. RAAR:

Review of Applied

Accounting Research, 1(2), 154-166.

\section{Office Address:}

Jl. K.H. Ahmad

Dahlan, Dukuhwaluh,

Kec. Kembaran,

Kabupaten Banyumas,

Jawa Tengah 53182

Kata Kunci: Wajib Pajak, PPh 21, Perpajakan Rumah Sakit

\begin{abstract}
This study aimed to analyze the implementation of the obligations of Hospital $X$ in Klaten on income tax Article 21. This study used a qualitative research method using a descriptive approach. The data used are primary and secondary data which were collected through observation, interviews, and documentation. The data analysis technique used descriptive analysis and comparative analysis. The results of this study indicate that from 2017 to 2019, Hospital X, in carrying out its obligations for income tax article 21, was carried out quite well, although there were still errors in some cases. Based on calculating and withholding PPh 21, Hospital X is still not under the tax law. In contrast to the calculation and withholding of PPh 21 taxes, the activities of depositing and reporting taxes at Hospital X from 2017 to 2019 have carried out their obligations promptly and by applicable rules or laws.
\end{abstract}

Keywords: Taxpayer, PPh 21, Hospital Tax

e-ISSN : 2807-8969 


\section{PENDAHULUAN}

155 Pajak yang berasal dari masyarakat memegang peranan penting, yaitu sebagai salah satu sumber pemasukan negara terbanyak. Menurut laporan hasil realisasi pendapatan Direktorat Jendral Pajak terkait pendapatan pajak yang diterima oleh pemerintah selama kurun waktu 2013-2019 terus mengalami peningkatan, sedangkan pajak penghasilan masih menjadi penyumbang terbesar dalam penerimaan pajak. Mekanisme pemungutan pajak di Indonesia saat ini menggunakan sistem Self assessment. Indah Kurniyawati (2019) menyatakan dalam penelitiannya bahwa ada kesalahan dalam Perhitungan Pajak Penghasilan Pasal 21 pada PT. X. Perhitungan tersebut menghasilkan lebih bayar yang mengakibatkan pembayar pajak mengalami kerugian. Penelitian Ni Made Tika Anggreni dan Naniek Noviari (2020) juga menyatakan bahwa perhitungan yang dilakukan oleh Rumah Sakit XYZ sudah benar, tetapi untuk penyetoran dan pelaporan PPh Pasal 21 yang telah diterapkan oleh Rumah Sakit XYZ belum sesuai dengan Undang-Undang. Hal ini kemudian menyebabkan adanya kewajiban kontijensi yang harus dilunasi.

Chris Waraney Rondonuwu, Inggriani Elim dan Sherly Pinatik (2017) dalam penelitiannya juga menyatakan bahwa pelaksanaan penghitungan dan pengurangan Pendapatan Pajak Pasal 21 untuk pegawai tetap belum sejalan dengan Peraturan Pajak pasal 36 Tahun 2008 dan PMK no. 101/PMK.010/2016. Nabella L. Baguna, Sifirid S. Pangemanan dan Treesje Runtu (2017) dalam penelitiannya juga menemukan adanya kesalahan dalam Perhitungan Pajak Penghasilan Pasal 21 di PT. Bank Rakyat Indonesia Cabang Manado, sehingga wajib pajak menimbulkan kerugian. Dalam penelitian yang dilakukan oleh Winesthy Anasthazia Handaputri Alfons, Treesje Runtu, dan Dhullo Afandi (2018) juga menyimpulkan bahwa dalam menentukan, memperkirakan dan pelaporan Penghasilan Pajak Pasal 21 di CV Unggul Abadi belum memenuhi aturan pajak terbaru.

Berdasarkan penelitian sebelumnya terlihat bahwa masih terdapat perusahaan yang dalam penerapan pemotongan pajak belum sesuai dengan ketentuan perpajakan yang berlaku. Hal ini jelas berdampak besar bagi pemerintah, karyawan sebagai pihak yang dipungut dan juga perusahaan sebagai pihak pemungut. Rumah sakit merupakan sebuah institusi yang padat karya atau menyerap banyak tenaga kerja baik tenaga medis maupun non medis dan juga merupakan sumber penerimaan pajak terbesar di bidang industri kesehatan, sehingga penelitian ini perlu mengambil rumah sakit sebagai objek yang perlu diteliti. Berdasarkan uraian di atas maka peneliti bermaksud melakukan penelitian dengan mengambil judul "Analisis Pelaksanaan Kewajiban Atas Pajak Penghasilan Pasal 21 Pada Rumah Sakit X Di Klaten" dengan tujuan untuk mengetahui apakah dalam pelaksanaan kewajiban atas pajak penghasilan pasal 21 Rumah Sakit X di Klaten telah sesuai dengan Undang-Undang Perpajakan yang berlaku.

\section{TINJAUAN TEORI}

\section{Pajak}

Undang-Undang Nomor 28 Tahun 2007 tentang Ketentuan Umum dan Tata Cara Perpajakan, Pasal 1 ayat 1 dijelaskan bahwa pajak merupakan kontribusi wajib kepada negara yang terutang oleh wajib pajak orang pribadi maupun badan yang bersifat memaksa

RAAR Vol.1 No.2 dengan berdasarkan undang-undang, dengan tidak mendapatkan imbalan secara langsung dan digunakan untuk kepentingan negara bagi sebesar-besarnya kemakmuran rakyat. Sehingga dalam hal ini membayar pajak adalah kewajiban yang tidak bisa dihindarkan dan 
merupakan sebuah keharusan bagi masyarakat khususnya bagi yang merupakan wajib pajak.

\section{Pajak Rumah Sakit}

\section{Pajak Penghasilan}

Pajak penghasilan menurut Undang-Undang Perpajakan No. 17 Tahun 2000 Pasal 4 ayat 1 merupakan setiap tambahan kemampuan ekonomi yang diterima atau diperoleh wajib pajak baik yang berasal dari indonesia yang dapat dipakai untuk konsumsi atau untuk kekayaan wajib pajak yang bersangkutan dengan nama dan dalam bentuk apapun. Pajak penghasilan di rumah sakit sendiri terdiri dari dua jenis yaitu pajak penghasilan orang pribadi dan pajak penghasilan badan.

2. Pajak Pertambahan Nilai

Pajak pertambahan nilai yang diberlakukan di rumah sakit sendiri berkaitan dengan penyerahan obat kepada pasien. Dalam hal ini sesuai dengan surat edaran Direktur Jendral Pajak No: SE-06/PJ.52/ 2000 tanggal 2 Maret 2000 tentang PPN atas Penggantian Obat di Rumah Sakit, ditegaskan bahwa instalasi farmasi (kamar obat) merupakan suatu tempat untuk mengadakan dan menyimpan obat-obatan, gas medik alat kesehatan serta bahan kimia yang bukan berdiri sendiri tetapi merupakan satuan organic yang tidak terpisah dari keseluruhan rumah sakit. Selanjutnya ditegaskan bahwa penyerahan obat-obatan yang dilakukan instalasi farmasi (kamar obat) tidak terutang PPN. Namun rumah sakit akan tetap terutang PPN jika melakukan pelayanan pada pasien rawat jalan karena dalam hal ini tidak terdapat perbedaan perlakuan PPN dengan apotek rawat jalan.

\section{Pajak Penghasilan Pasal 21}

PPh Pasal 21 adalah pajak atas penghasilan berupa gaji, upah, honorarium, tunjangan, dan pembayaran lain dengan nama dan dalam bentuk apapun sehubungan dengan pekerjaan atau jabatan, jasa, dan kegiatan yang dilakukan oleh orang pribadi Subjek Pajak negeri, sebagaimana dimaksud dalam Pasal 21 Undang-Undang Pajak Penghasilan.

\section{Sumber Daya Manusia Rumah Sakit}

Kebutuhan manajemen terkait sumber daya manusia yang ada dirumah sakit menurut Permenkes No. 340 Tahun 2010 Tentang Klasifikasi Rumah Sakit pada pasal 21 menyebutkan bahwa manajemen rumah sakit setidaknya harus terdiri dari:

1. Kepala Rumah Sakit atau Direktur

2. Unsur pelayanan Medis

3. Unsur Keperawatan

4. Unsur penunjang Medis

5. Komite Medis

6. Satuan Pemeriksa Internal

7. Administrasi Umum dan Kuangan

\section{METODE PENELITIAN}

Pendekatan penelitian dalam penelitian ini adalah deskriptif kualitatif yaitu penelitian yang bersifat menjelaskan untuk mengumpulkan, menganalisis serta membandingkan pengetahuan teknis (data primer) dengan keadaan yang sebenarnya pada perusahaan untuk mengambil kesimpulan. Obyek penelitian ini adalah Rumah Sakit X di Kabupaten Klaten Provinsi Jawa Tengah dan perhitungan PPh Pasal 21 pegawai tahun 2017-2019 yang 
dilakukan rumah sakit. Penyebutan nama rumah sakit dalam penelitian ini adalah Rumah Sakit X. Hal ini dikarenakan permintaan dari objek yang diteleti untuk merahasiakan identitas aslinya. Demi menjaga etika penelitian, maka peneliti menggunakan identitas inisial dari objek yang diteliti.

Penelitian ini akan menggunakan jenis data primer dan data sekunder. Data primer berupa informasi langsung tentang bagaimana pelaksanaan pemenuhan kewajiban, bagaimana sistem perhitungan, pemotongan dan pelaporan yang dilaksanakan rumah sakit dan juga terkait bagaimana penetapan penghasilan yang diperoleh pegawai seperti gaji, upah, tunjangan dan penghasilan lainnya. Data sekunder berupa rekap laporan yang berhubungan dengan PPh 21 tahun 2017-2019 seperti gaji, upah, honorarium, tunjangan, dan pembayaran lain dengan nama dan dalam bentuk apapun sehubungan dengan pekerjaan atau jabatan, jasa dan kegiatan yang dilakukan oleh orang pribadi, status karyawan, NPWP, rekap SPT Masa PPh 21 dan tanda terima SPT Masa PPh 21. Teknik pengumpulan data dilakukan dengan Observasi, wawancara dan dokumentasi. Teknik yang digunakan peneliti untuk memeriksa dan menetapkan validitas atas penelitian yang dilakukan yaitu dengan triangulasi.

Teknik analisis data yang digunakan oleh penulis dalam penelitian ini adalah analisis deskriptif dan komparatif. Tahapan Analisis data penelitian ini :

1 Mengumpulkan data tentang laporan pajak penghasilan pasal 21 pegawai periode 20172019

2 Menghitung ulang terhadap data yang diperoleh seperti gaji, upah, honorarium, tunjangan, dan pembayaran lain. Perhitungan tersebut didasarkan atas nama pegawai, pekerjaan atau jabatan, jasa dan kegiatan yang dilakukan oleh orang pribadi untuk penentuan pajak yang dipungut dengan mengacu pada peraturan perpajakan yang berlaku.

3 Membandingkan perhitungan pajak penghasilan pasal 21 yang telah dilakukan oleh Rumah Sakit X di Klaten dengan yang dilakukan oleh penulis.

4 Melakukan Analisis pelaporan pajak, apakah sudah sesuai dengan peraturan perpajakan.

5 Jika ada ketidaksesuaian perhitungan maupun pelaporan oleh rumah sakit maka akan dilakukan analisis permasalahan yang terjadi.

6 Penarikan kesimpulan dan saran.

\section{HASIL DAN PEMBAHASAN}

Pada saat awal berdiri, Rumah Sakit X masih berupa balai pengobatan sederhana yang hingga saat ini berubah menjadi rumah sakit umum. Jumlah sumber daya manusia yang ada di Rumah Sakit X terus mengalami peningkatan seiring berjalannya waktu. Pada tahun 2017 Rumah Sakit X memiliki karyawan baik pegawai tetap maupun mitra berjumlah 100 orang, kemudian pada tahun 2018 naik menjadi 132 pegawai dan pada tahun 2019 naik menjadi 187 orang.

Jenis sumber daya manusia yang ada pada Rumah Sakit X terdiri dari dokter tetap, dokter RAAR mitra, karyawan tetap, karyawan kontrak dan karyawan OJT (On The Job Training). Vol.1 No.2 Karyawan yang sudah melaksanakan kewajibannya dalam hal pemenuhan pajak atau yang sudah memenuhi kriteria sebagai wajib pajak di Rumah Sakit X ini merupakan dokter. 
Pada tahun 2017 sejumlah 13 orang, kemudian pada tahun 2018 dan tahun 2019 sejumlah 11 orang.

Pengelolaan pajak yang dilakukan Rumah Sakit X dalam rentang waktu 2017 sampai tahun 2019 belum dikelola oleh bagian yang khusus mengurus pengelolaan pajak atau masih menjadi satu dengan karyawan yang mengurusi terkait pelaksanaan keuangan. Dikhawatirkan akan ada kesalahan yang bisa saja terjadi dalam hal pelaksanaan kewajiban khususnya terkait pajak penghasilan pasal 21 jika tidak dikelola oleh bagian yang memang ahli dibidangnya.

\section{Komitmen Rumah Sakit X Terhadap Pajak}

Rumah Sakit X selama ini telah berkomitmen untuk selalu taat dalam melaksanakan kewajibannya dalam membayar pajak. Rumah Sakit X telah melakukan pembayaran pajak seperti pembayaran pajak badan, pajak penghasilan pasal 21, Pajak Bumi dan Bangunan (PBB) dan Pajak Daerah. Saat ini Rumah Sakit X belum melakukan pembayaran pajak terkait PPN dikarenakan rumah sakit masih tergolong sebagai entitas bisnis kecil. Rumah Sakit X selama satu tahun buku melakukan penyerahan barang kena pajak dan atau jasa kena pajak dengan jumlah peredaran brutonya tidak melebihi Rp 4.800.000.000 (empat milyar delapan ratus juta rupiah). Sesuai dengan Peraturan Mentri keuangan nomor 197/PMK.03/2013 pada pasal 1 ayat 1, menyatakan bahwa pengusaha kecil dapat memilih untuk dikukuhkan sebagai pengusaha kena pajak atau tidak.

Rumah Sakit $\mathrm{X}$ dari tahun ke tahun mengalami naik-turun dalam pembayaran pajak khususnya dalam pembayaran pajak penghasilan pasal 21. Gambar 4.1 memperlihatkan grafik pembayaran pajak PPh 21 pada Rumah Sakit X. Pada tahun 2017 rumah sakit telah melaksanakan kewajibannya atas pajak penghasilan pasal 21 sebesar $\mathrm{Rp} 22.413 .540$, kemudian pada tahun 2018 mengalami kenaikan sebesar 51\% dari jumlah pembayaran pajak tahun sebelumnya sehingga pajak yang dibayarkan menjadi Rp 45.941 .112 dan pada tahun 2019 mengalami penurunan sebesar 9\% dari tahun sebelumnya menjadi $\mathrm{Rp}$ 41.875.586.

Rumah Sakit X sampai saat ini belum melakukan perencanaan pajak. Pada tahun 2021 ini Rumah Sakit X baru akan merancang perencanaan pajak yang nantinya akan di terapkan di Rumah Sakit X. Perencanaan pajak sendiri merupakan hal yang cukup membantu bagi perusahaan atau instansi yang merupakan pengusaha kena pajak dalam hal manajemen laba. Adanya perencanaan pajak ini dapat membantu untuk membuat beban pajak yang harus dibayar dapat ditekan serendah mungkin dengan memanfaatkan peraturan perpajakan yang ada (Dalimunthe, 2018). Perencanaan pajak ini juga merupakan upaya yang dapat dilakukan untuk mengatur pembayaran pajak atau meminimalkan kewajiban pajak dengan tidak melanggar peraturan perundang-undangan yang berlaku, agar pajak yang dibayarkan tidak lebih dari jumlah yang seharusnya

\section{Pelaksanaan Pajak PPh Pasal 21 Pada Rumah Sakit X}

\section{Perhitungan Pajak}

Perhitungan pajak penghasilan PPh pasal 21 yang dilakukan oleh Rumah Sakit X belum sepenuhnya sesuai dengan peraturan perpajakan yang berlaku. Hal ini dibuktikan melalui penelaahan SPT Masa PPh pasal 21 dari bulan Januari sampai desember tahun 2017 sampai 2019. Dasar pengenaan pajak Rumah Sakit X memakai dasar pengenaan 
pajak yaitu 50\% dari jumlah penghasilan bruto yang sudah dipotong bagi hasil dengan Rumah Sakit X. Penetapan dasar pengenaan pajak yang dilakukan oleh Rumah Sakit X ini jelas tidak sesuai dengan Peraturan Direktur Jenderal Pajak Nomor PER-16/PJ/2016.

Peraturan tersebut menyatakan bahwa pemotongan pajak penghasilan pasal 21 bagi orang pribadi dalam negeri bukan pegawai atas imbalan yang bersifat berkesinambungan yang memperoleh penghasilan lainnya selain dari hubungan kerja dengan pemotong PPh pasal 21 dan atau tidak memiliki NPWP. PPh pasal 21 dihitung dengan menerapkan tarif pasal 17 ayat (1) huruf a UU PPh atas jumlah kumulatif 50\% (lima puluh persen) dari jumlah penghasilan bruto dalam tahun kalender yang bersangkutan. Sedangkan pemotongan $\mathrm{PPh}$ pasla 21 bagi orang pribadi dalam negri bukan pegawai atas imbalan yang tidak bersifat berkesinambungan, $\mathrm{PPh}$ pasal 21 dihitung dengan menerapkan tarif pasal 17 ayat 1 huruf a UU PPh atas 50\% dari jumlah penghasilan bruto.

Bukan pegawai sebagaimana yang dimaksud pada ketentuan di atas adalah dokter yang melakukan praktik di rumah sakit dan atau klinik, maka besarnya jumlah penghasilan bruto adalah sebesar jasa dokter yang dibayarkan pasien melalui rumah sakit dan atau klinik sebelum dipotong biaya-biaya atau bagi hasil oleh rumah sakit atau klinik. Rumah Sakit X dalam hal penentuan dasar penetapaan pajak rumah sakit disini masih belum sesuai. Penetapan tarif yang dilakukan oleh Rumah Sakit X juga belum menggunakan tarif yang sesuai yaitu tarif pasal 17 ayat 1 UU Nomor 36 Tahun 2008 tentang pajak penghasilan.

Menurut undang-undang tentang pajak penghasilan tersebut seharusnya tarif akan mengalami peningkatan dikarenakan perhitungan menggunakan jumlah kumulatif dari jumlah bruto dalam tahun kalender yang bersangkutan, namun Rumah Sakit X setiap masa pajak menggunakan tarif yang sama yaitu 5\%. Hal tersebut mengakibatkan adanya kurang bayar pada akhir tahun yang harus diurus oleh para wajib pajak masing-masing. Hal ini cukup kurang efektif karena staf bagian keuangan yang memegang tanggung jawab untuk melakukan pemotongan kurang mengetahui sistem yang ada, sehingga tidak bisa merubah tarif yang ada pada sistem dan sampai sekarang belum menemukan bagaimana cara untuk megubahnya.

\section{Pemotongan Pajak}

Perbedaan perhitungan pajak yang telah dilakukan oleh Rumah Sakit X dengan peraturan perpajakan yang ada dapat dilihat pada Tabel 1 dan 2 di bawah ini:

Tabel 1: Perhitungan Pajak yang Dilakukan Rumah Sakit X

\begin{tabular}{|c|c|c|c|c|}
\hline Bulan & $\begin{array}{c}\text { Penghasilan } \\
\text { Bruto }\end{array}$ & $\begin{array}{c}\text { PKP }(50 \% \times \\
\text { Bruto) }\end{array}$ & Tarif & PPh Dipotong \\
\hline Januari & Rp 100.623.000 & $\operatorname{Rp} 50.311 .500$ & $5 \%$ & $\operatorname{Rp} 2.515 .575$ \\
\hline $\begin{array}{l}\text { Februar } \\
\text { i }\end{array}$ & $\mathrm{Rp} \quad 90.873 .000$ & $\mathrm{Rp} \quad 45.436 .500$ & $5 \%$ & Rp 2.271.825 \\
\hline Maret & Rp 73.861 .000 & Rp 36.930 .500 & $5 \%$ & Rp 1.846.525 \\
\hline Jumlah & Rp 265.357.000 & Rp 132.678.500 & & Rp 6.633.925 \\
\hline
\end{tabular}


Tabel 2: Perhitungan Pajak Menurut Peraturan Perpajakan

\begin{tabular}{|c|c|c|c|c|c|c|c|}
\hline Bulan & $\begin{array}{c}\text { Penghasilan } \\
\text { Bruto }\end{array}$ & & $\begin{array}{c}\text { PKP (50\% } x \\
\text { Bruto) }\end{array}$ & $\begin{array}{c}\text { PKP } \\
\text { Kumulatif }\end{array}$ & & & $\begin{array}{c}\text { PPh } \\
\text { Dipotong }\end{array}$ \\
\hline \multirow[t]{2}{*}{ Januari } & Rp 100.623.000 & $\mathrm{Rp}$ & 50.000 .000 & $\begin{array}{l}\mathrm{Rp} \\
50.000 .000\end{array}$ & $5 \%$ & $\mathrm{Rp}$ & 2.500 .000 \\
\hline & & $\mathrm{Rp}$ & 311.500 & $\begin{array}{l}\mathrm{Rp} \\
50.311 .500\end{array}$ & $15 \%$ & $\mathrm{Rp}$ & 46.725 \\
\hline $\begin{array}{l}\text { Februar } \\
\text { i }\end{array}$ & Rp 90.873 .000 & $\mathrm{Rp}$ & 45.436 .500 & $\begin{array}{l}\mathrm{Rp} \\
95.748 .000\end{array}$ & $15 \%$ & $\mathrm{Rp}$ & 6.815 .475 \\
\hline Maret & 73.861 .000 & $\mathrm{Rp}$ & 36.930 .500 & $\begin{array}{l}\mathrm{Rp} \\
132.678 .500\end{array}$ & $15 \%$ & $\mathrm{Rp}$ & 5.539 .575 \\
\hline Jumlah & Rp 265.357.000 & & 132.678 .500 & & & & 01.775 \\
\hline
\end{tabular}

Sumber: Peraturan Direktur Jendral Pajak Nomor PER-16/PJ/2016

Pemotongan pajak yang dilakukan oleh Rumah Sakit X selama ini masih melakukan pemotongan secara terpisah antara pendapatan dari pembayaran umum dan BPJS. Dapat dilihat dari tabel 4.4 di atas bahwa Rumah Sakit X juga dalam menentukan jumlah pemotongan dengan tidak menggunakan sistem penghasilan kena pajak kumulatif dimana tarif pajak yang ada seharusnya akan naik seiring besarnya jumlah penghasilan yang telah diakumulasikan setiap bulannya. Tarif 5\% akan diberlakukan jika besarnya penghasilan dari 0 sampai $\mathrm{Rp} 50.000 .000$, tarif $15 \%$ diterapkan jika jumlah penghasilan kena pajak kumulatif antara Rp 50.000.000 sampai Rp 250.000.000, tarif 25\% akan diterapkan jika jumlah penghasilan antara Rp 250.000.000 sampai dengan Rp 500.000 .000 dan tarif 30\% akan diterapkan jika penghasilan kena pajak kumulatif dari Rp 500.000.000 keatas. Hal ini mengakibatkan wajib pajak diakhir tahun akan mengalami penyesuaian yang nantinya akan terjadi kurang bayar.

\section{Penyetoran dan Pelaporan Pajak}

Berikut ini merupakan tabel perbandingan terkait tanggal penyetoran SPT Masa pajak penghasilan pasal 21 yang telah dilakukan Rumah Sakit X dengan ketentuan perpajakan yang berlaku. Dapat dilihat pada Tabel 3, 4 dan 5.

Tabel 3: Analisa Penyetoran Masa SPT PPh 21 Rumah Sakit X (2017)

\begin{tabular}{|c|c|c|c|}
\hline $\begin{array}{c}\text { SPT } \\
\text { MASA }\end{array}$ & $\begin{array}{c}\text { Tanggal } \\
\text { Penyetoran Sesuai } \\
\text { Aturan } \\
\end{array}$ & $\begin{array}{c}\text { Tanggal } \\
\text { Penyetoran } \\
\text { Rumah Sakit X } \\
\end{array}$ & Analisa \\
\hline Januari & 10 Februari 2017 & 03 Februari 2017 & Tepat Waktu \\
\hline Februari & 10 Maret 2017 & 02 Maret 2017 & Tepat Waktu \\
\hline Maret & 10 April 2017 & 03 April 2017 & Tepat Waktu \\
\hline April & 10 Mei 2017 & 03 Mei 2017 & Tepat Waktu \\
\hline Mei & 10 Juni 2017 & 02 Juni 2017 & Tepat Waktu \\
\hline Juni & 10 Juli 2017 & 03 Juli 2017 & Tepat Waktu \\
\hline Juli & 10 Agustus 2017 & 02 Agustus 2017 & Tepat Waktu \\
\hline
\end{tabular}

RAAR

Vol.1 No.2 
Agustus 10 September 201729 Agustus $2017 \quad$ Tepat Waktu

September 10 Oktober $2017 \quad 29$ September 2017 Tepat Waktu

Oktober 10 November 201730 Oktober $2017 \quad$ Tepat Waktu

November 10 Desember 201729 November 2017 Tepat Waktu

Desember 10 Januari $2018 \quad 29$ Desember 2017 Tepat Waktu

Sumber: Rumah Sakit X (Data diolah, 2021)

Tabel 4: Analisa Penyetoran Masa SPT PPh 21 Rumah Sakit X (2018)

\begin{tabular}{|c|c|c|c|}
\hline $\begin{array}{c}\text { SPT } \\
\text { MASA }\end{array}$ & $\begin{array}{c}\text { Tanggal } \\
\text { Penyetoran Sesuai } \\
\text { Aturan } \\
\end{array}$ & $\begin{array}{c}\text { Tanggal } \\
\text { Penyetoran } \\
\text { Rumah Sakit X } \\
\end{array}$ & Analisa \\
\hline Januari & 10 Februari 2018 & 30 Januari 2018 & Tepat Waktu \\
\hline Februari & 10 Maret 2018 & 01 Maret 2018 & Tepat Waktu \\
\hline Maret & 10 April 2018 & 29 Maret 2018 & Tepat Waktu \\
\hline April & 10 Mei 2018 & 27 April 2018 & Tepat Waktu \\
\hline Mei & 10 Juni 2018 & 26 Mei 2018 & Tepat Waktu \\
\hline Juni & 10 Juli 2018 & 28 Juni 2018 & Tepat Waktu \\
\hline Juli & 10 Agustus 2018 & 27 Juli 2018 & Tepat Waktu \\
\hline Agustus & 10 September 2018 & 29 Agustus 2018 & Tepat Waktu \\
\hline September & 10 Oktober 2018 & 28 September 2018 & Tepat Waktu \\
\hline Oktober & 10 November 2018 & 29 Oktober 2018 & Tepat Waktu \\
\hline November & 10 Desember 2018 & 27 November 2018 & Tepat Waktu \\
\hline Desember & 10 Januari 2019 & 28 Desember 2018 & Tepat Waktu \\
\hline
\end{tabular}

Sumber: Rumah Sakit X (Data diolah, 2021)

Tabel 5: Analisa Penyetoran Masa SPT PPh 21 Rumah Sakit X (2019)

\begin{tabular}{llll}
\hline \multicolumn{1}{c}{ SPT } & \multicolumn{1}{c}{$\begin{array}{c}\text { Tanggal } \\
\text { Penyetoran Sesuai } \\
\text { Aturan }\end{array}$} & $\begin{array}{c}\text { Tanggal } \\
\text { Penyetoran } \\
\text { Rumah Sakit X }\end{array}$ & Analisa \\
\hline Januari & 10 Februari 2019 & 30 Januari 2019 & Tepat Waktu \\
Februari & 10 Maret 2019 & 27 Februari 2019 & Tepat Waktu \\
Maret & 10 April 2019 & 27 Maret 2019 & Tepat Waktu \\
April & 10 Mei 2019 & 27 April 2019 & Tepat Waktu \\
Mei & 10 Juni 2019 & 28 Mei 2019 & Tepat Waktu \\
Juni & 10 Juli 2019 & 27 Juni 2019 & Tepat Waktu \\
Juli & 10 Agustus 2019 & 27 Juli 2019 & Tepat Waktu \\
Agustus & 10 September 2019 & 27 Agustus 2019 & Tepat Waktu \\
September & 10 Oktober 2019 & 27 September 2019 & Tepat Waktu \\
Oktober & 10 November 2019 & 29 Oktober 2019 & Tepat Waktu \\
November & 10 Desember 2019 & 27 November 2019 & Tepat Waktu \\
Desember & 10 Januari 2020 & 28 Desember 2019 & Tepat Waktu \\
\hline Sumber: Rumah Sakit X (Data diolah, 2021) &
\end{tabular}

Kesimpulan yang dapat ditarik dalam hal penyetoran pajak dari tahun 2017 sampai dengan 2019 yaitu, Rumah Sakit X telah melakukan penyetoran pajak dengan tepat 
waktu sesuai dengan masa pajak yang telah ditetapkan yaitu sebelum masa pajak berakhir dimana rentang waktu yang ditetapkan paling lama 10 hari setelah masa pajak berakhir. SPT masa pajak ini dilaporkan lengkap dengan cap dan tanda tangan direktur rumah sakit dan dilampirkan bukti bayar berupa Bukti Penerimaan Surat (BPS).

Perbandingan terkait tanggal pelaporan SPT Masa pajak penghasilan pasal 21 yang telah dilakukan Rumah Sakit X dengan ketentuan perpajakan yang berlaku dapat dilihat pada Tabel 6, 7 dan 8 di bawah ini:

Tabel 6: Analisa Pelaporan Masa SPT PPh 21 Rumah Sakit X (2017)

\begin{tabular}{|c|c|c|c|}
\hline $\begin{array}{c}\text { SPT } \\
\text { MASA }\end{array}$ & $\begin{array}{l}\text { Tanggal Pelaporan } \\
\text { Sesuai Aturan }\end{array}$ & $\begin{array}{c}\text { Tanggal } \\
\text { Pelaporan Rumah } \\
\text { Sakit X }\end{array}$ & Analisa \\
\hline Januari & 20 Februari 2017 & 16 Februari 2017 & Tepat Waktu \\
\hline Februari & 20 Maret 2017 & 13 Maret 2017 & Tepat Waktu \\
\hline Maret & 20 April 2017 & 11 April 2017 & Tepat Waktu \\
\hline April & 20 Mei 2017 & 09 Mei 2017 & Tepat Waktu \\
\hline Mei & 20 Juni 2017 & 14 Juni 2017 & Tepat Waktu \\
\hline Juni & 20 Juli 2017 & 14 Juli 2017 & Tepat Waktu \\
\hline Juli & $\begin{array}{l}20 \text { Agustus } 2017 \\
20 \text { September }\end{array}$ & 08 Agustus 2017 & Tepat Waktu \\
\hline Agustus & 2017 & 11 September 2017 & Tepat Waktu \\
\hline September & $\begin{array}{l}20 \text { Oktober } 2017 \\
20 \text { November }\end{array}$ & 06 Oktober 2017 & Tepat Waktu \\
\hline Oktober & $\begin{array}{l}2017 \\
20 \text { Desember }\end{array}$ & 13 November 2017 & Tepat Waktu \\
\hline November & 2017 & 11 Desember 2017 & Tepat Waktu \\
\hline Desember & 20 Januari 2018 & 11 Januari 2018 & Tepat Waktu \\
\hline
\end{tabular}

Sumber: Rumah Sakit X (Data diolah, 2021)

Tabel 7: Analisa Pelaporan Masa SPT PPh 21 Rumah Sakit X (2018)

\begin{tabular}{|c|c|c|c|c|}
\hline $\begin{array}{c}\text { SPT } \\
\text { MASA }\end{array}$ & $\begin{array}{c}\text { Tanggal Pelaporan } \\
\text { Sesuai Aturan }\end{array}$ & $\begin{array}{c}\text { Tanggal } \\
\text { Pelaporan Rumah } \\
\text { Sakit X }\end{array}$ & Analisa & \\
\hline Januari & 20 Februari 2018 & 14 Februari 2018 & $\begin{array}{l}\text { Tepat } \\
\text { Waktu } \\
\text { Tepat }\end{array}$ & \\
\hline Februari & 20 Maret 2018 & 09 Maret 2018 & $\begin{array}{l}\text { Waktu } \\
\text { Tepat }\end{array}$ & \\
\hline Maret & 20 April 2018 & 13 April 2018 & $\begin{array}{l}\text { Waktu } \\
\text { Tepat }\end{array}$ & \\
\hline April & 20 Mei 2018 & 07 Mei 2018 & $\begin{array}{l}\text { Waktu } \\
\text { Tepat }\end{array}$ & \\
\hline Mei & 20 Juni 2018 & 07 Juni 2018 & $\begin{array}{l}\text { Waktu } \\
\text { Tepat }\end{array}$ & $\begin{array}{l}\text { RAAK } \\
\text { Vol.1 No.2 }\end{array}$ \\
\hline Juni & 20 Juli 2018 & 11 Juli 2018 & Waktu & \\
\hline
\end{tabular}




\begin{tabular}{|c|c|c|c|c|}
\hline & Juli & 20 Agustus 2018 & 10 Agustus 2018 & $\begin{array}{l}\text { Tepat } \\
\text { Waktu } \\
\text { Tepat }\end{array}$ \\
\hline \multirow{19}{*}{163} & Agustus & 20 September 2018 & 08 September 2018 & $\begin{array}{l}\text { Waktu } \\
\text { Tepat }\end{array}$ \\
\hline & September & 20 Oktober 2018 & 05 Oktober 2018 & $\begin{array}{l}\text { Waktu } \\
\text { Tepat }\end{array}$ \\
\hline & Oktober & 20 November 2018 & 09 November 2018 & $\begin{array}{l}\text { Waktu } \\
\text { Tepat }\end{array}$ \\
\hline & November & 20 Desember 2018 & 11 Desember 2018 & $\begin{array}{l}\text { Waktu } \\
\text { Tepat }\end{array}$ \\
\hline & Desember & 20 Januari 2019 & 04 Januari 2019 & Waktu \\
\hline & $\begin{array}{l}\text { Sumber: } \mathrm{F} \\
\text { Tabel 8: }\end{array}$ & $\begin{array}{l}\text { mah Sakit X (Data dio } \\
\text { alisa Pelaporan Masa }\end{array}$ & $\begin{array}{l}\text { ah, 2021) } \\
\text { PT PPh } 21 \text { Rumah Sa }\end{array}$ & kit X (2019) \\
\hline & $\begin{array}{c}\text { SPT } \\
\text { MASA }\end{array}$ & $\begin{array}{c}\text { Tanggal Pelaporan } \\
\text { Sesuai Aturan }\end{array}$ & $\begin{array}{c}\text { Tanggal } \\
\text { Pelaporan Rumah } \\
\text { Sakit X } \\
\end{array}$ & Analisa \\
\hline & Januari & 20 Februari 2019 & 08 Februari 2019 & $\begin{array}{l}\text { Tepat } \\
\text { Waktu } \\
\text { Tepat }\end{array}$ \\
\hline & Februari & 20 Maret 2019 & 09 Maret 2019 & $\begin{array}{l}\text { Waktu } \\
\text { Tepat }\end{array}$ \\
\hline & Maret & 20 April 2019 & 05 April 2019 & $\begin{array}{l}\text { Waktu } \\
\text { Tepat }\end{array}$ \\
\hline & April & 20 Mei 2019 & 08 Mei 2019 & $\begin{array}{l}\text { Waktu } \\
\text { Tepat }\end{array}$ \\
\hline & Mei & 20 Juni 2019 & 10 Juni 2019 & $\begin{array}{l}\text { Waktu } \\
\text { Tepat }\end{array}$ \\
\hline & Juni & 20 Juli 2019 & 06 Juli 2019 & $\begin{array}{l}\text { Waktu } \\
\text { Tepat }\end{array}$ \\
\hline & Juli & 20 Agustus 2019 & 09 Agustus 2019 & $\begin{array}{l}\text { Waktu } \\
\text { Tepat }\end{array}$ \\
\hline & Agustus & 20 September 2019 & 11 September 2019 & $\begin{array}{l}\text { Waktu } \\
\text { Tepat }\end{array}$ \\
\hline & September & 20 Oktober 2019 & 03 Oktober 2019 & $\begin{array}{l}\text { Waktu } \\
\text { Tepat }\end{array}$ \\
\hline & Oktober & 20 November 2019 & 08 November 2019 & $\begin{array}{l}\text { Waktu } \\
\text { Tepat }\end{array}$ \\
\hline & November & 20 Desember 2019 & 06 Desember 2019 & $\begin{array}{l}\text { Waktu } \\
\text { Tepat }\end{array}$ \\
\hline & Desember & 20 Januari 2020 & 09 Januari 2020 & Waktu \\
\hline
\end{tabular}

Sumber: Rumah Sakit X (Data diolah, 2021)

RAAR Berdasarkan data yang sudah diperoleh di atas dapat ditarik kesimpulan terkait pelaporan Vol.1 No.2 SPT Masa PPh Pasal 21 bahwa Rumah Sakit X selama kurun waktu 2017 sampai dengan tahun 2019 selalu tepat waktu dalam melaporkan SPT Masanya. Hal ini dapat menghindarkan wajib pajak dari adanya sanksi bunga atas keterlambatan pelaporan pajak. 


\section{Perencanaan Pajak}

Perencanaan pajak merupakan hal yang dilakukan untuk meminimalkan besar pajak yang nantinya akan dibayarkan. Perencanaan pajak sendiri merupakan usaha penghindaran pajak yang diperbolehkan karena perencanaan dilakukan dilakukan berdasarkan skema yang sudah ada dan diatur dalam undang-undang perpajakan. Rumah Sakit X selama ini belum melakukan perencanaan pajak.

Pembayaran pajak penghasilan pasal 21 yang telah dilakukan oleh Rumah Sakit X selama ini dilakukan dengan teratur dan tepat waktu khususnya terkait penyetoran dan juga pelaporan. Hal ini dilakukan agar nantinya wajib pajak tidak akan mengalami kerugian dikarenakan harus membayar denda akibat telat membayar pajak. Terkait pembayaran pajak, wajib pajak menanggung sendiri jumlah pajak yang harus dibayarkan.

\section{KESIMPULAN DAN SARAN}

\section{Kesimpulan}

Berdasarkan analisis data yang telah dilakukan sebelumnya, dapat ditarik kesimpulan bahwa selama tahun 2017 sampai dengan 2019 Rumah Sakit X dalam melaksanakan kewajiban atas pajak penghasilan pasal 21 dilakukan dengan cukup baik, meskipun dalam beberapa hal masih terdapat kesalahan. Berdasakan aktivitas perhitungan dan pemotongan PPh 21, Rumah Sakit X masih belum sesuai dengan undang-undang perpajakan. Hal ini terjadi karena dalam hal penetapan dasar pengenaan pajak dan juga tarif yang digunakan oleh Rumah Sakit X tidak sesuai dengan Peraturan Direktur Jenderal Pajak yang berlaku. Salah satu faktor yang mengakibatkan terjadinya kesalahan yang ada karena staf bagian keuangan yang memegang tanggung jawab untuk melakukan pemotongan adalah kurangnya mengetahui pengoprasian sistem yang telah disediakan oleh Direktorat Jenderal Pajak, sehingga tidak bisa merubah tarif pada sistem yang mengakibatkan adanya kurang bayar pada akhir tahun.

Berbeda dengan perhitungan dan pemotongan pajak PPh 21 , aktivitas penyetoran dan pelaporan pajak Rumah Sakit X selama tahun 2017 sampai dengan 2019 sudah melaksanakan kewajibannya dengan tepat waktu dan sesuai aturan atau undang-undang yang ada. Rumah sakit X selama ini melakukan penyetoran pajak sebelum masa pajak berakhir dimana batas rentang waktu yang ditetapkan paling lama 10 hari setelah masa pajak berakhir. Terkait pelaporan pajak Rumah Sakit X juga selalu tepat waktu, hal ini juga dilakukan guna menghindarkan wajib pajak dari adanya sanksi denda atas keterlambatan pelaporan pajak. Hanya saja ketika terjadi kurang bayar hal ini seluruhnya menjadi urusan dan tanggungjawab dari masing-masing dokter sendiri dan bukan merupakan tanggungjawab dari pihak rumah sakit.

\section{Keterbatasan Penelitian}

Adapun keterbatasan dalam penelitian ini adalah sebagai berikut:

1. Data yang dimiliki Rumah Sakit X masih belum lengkap sehingga dalam hal pelaksanaan peneliti cukup terhambat khusunya terkait data rincian dari jumlah gaji yang diterima oleh dokter sehingga sulit untuk menentukan jumlah penghasilan bruto dokter sebelum dibagi hasil dengan Rumah Sakit X.

RAAR

Vol.1 No.2 
2. Salah satu wawancara dilakukan secara tidak langsung dikarenakan informan sedang melaksanakan isolasi mandiri.

\section{Saran}

Saran yang dapat diberikan kepada Rumah Sakit X yaitu sebaiknya rumah sakit melakukan penambahan karyawan yang memang ahli dibidang perpajakan. Rumah Sakit X juga disarankan untuk melakukan update terkait kebijakan perpajakan sehingga nantinya tidak ada lagi kesalahan dalam perhitungan maupun pemotongan pajak penghasilan pasal 21. Rumah Sakit X juga disarankan untuk melakukan perencanaan pajak sehingga kedepannya dapat membantu Rumah Sakit X untuk menekan jumlah pajak yang harus dibayarkan dengan memanfaatkan peraturan perpajakan yang ada.

Bagi peneliti selanjutnya disarankan dapat mengembangkan penelitian ini dengan menambahkan pembahasan yang lebih luas lagi. Serta disarankan untuk menggunakan periode yang lebih panjang lagi sehingga hasil penelitian yang didapatkan lebih akurat.

\section{REFERENSI}

Alfons, W.A.H, Dkk. (2018). Analisis Penerapan Pajak Penghasilan Pasal 21 pada CV Unggul Abadi di Manado, Jurnal Riset Akuntansi. Vol. 13, No. 2. Hal. 668-682.

Anggaran Pendapatan dan Belanja Negara Tahun 2019, diakses pada 21 Februari 2021 dari www.kemenkeu.go.id.

Anggreni, N.M.T, dan Noviari, N. (2020). Analisis Pelaksanaan Kewajiban atas Pajak Penghasilan Pasal 21 Pada Rumah Sakit XYZ, Jurnal Ekonomi dan Bisnis Universitas Udayana. Vol. 9, No. 1. Hal. 39-56.

Baguna, Nabella L, Dkk. (2017). Analisis Perhitungan dan Pelaporan Pajak Penghasilan Pasal 21 Pegawai Tetap pada PT. Bank Indonesia Kantor, Jurnal Riset Akuntansi. Vol. 12, No. 2. Hal. 327-335.

Dalimunthe, M. I. (2018). Pengaruh Perencanaan Pajak Terhadap Manajemen Laba Pada Sub Sektor Pertambangan Logam dan Mineral yang Terdaftar Di Bursa Efek Indonesia, Jurnal Mutiara Akuntansi . Vol. 3, No.2.

Kurniyawati, Indah. (2019). Analisis Penerapan Perhitungan dan Pelaporan Pajak Penghasilan $(\mathrm{PPh})$ Pasal 21 atas Karyawan Tetap Pada PT X di Surabaya, Jurnal Penelitian Ekonomi dan Akuntansi (JPENSI). Vol. 1, No. 2.

Peraturan Direktur Jendral Pajak Nomor Per-16/PJ/2016 Tentang Pedoman Teknis Tata Cara Pemotongan, Penyetoran dan Pelaporan Pajak Penghasilan Pasal 21 dan/atau Pajak Penghasilan Pasal 26 Sehubungan Dengan Pekerjaan, Jasa dan Kegiatan Orang Pribadi.

Peraturam Menteri Kesehatan Nomor 340/MENKES/PER/III/2010 Tentang Klasifikasi Rumah Sakit.

\section{RAAR}

Vol.1 No.2

Peraturan Menteri Keuangan Nomor 197/PMK.03/2013 Tentang Perubahan Atas Peraturan Menteri Keuangan Nomor 68/PMK.03/2010 Tentang Batasan Pengusaha Kecil Pajak Pertambahan Nilai. 
Rondonuwu, Chris, W., Dkk (2017). Analisis Penerapan Perhitungan dan Pemotongan Pajak Penghasilan Pasal 21 Rumah Sakit Pancaran Kasih Manado, Jurnal Riset Akuntansi. Vol. 12, No. 1. Hal. 48-53.

Surat Edaran Direktur Jendral Pajak No: SE-06/PJ.52/ 2000 tanggal 2 Maret 2000 tentang PPN atas Penggantian Obat di Rumah Sakit

Undang-Undang Nomor 17 Tahun 2000 tentang Perubahan Ketiga atas Undang-Undang Nomor 7 Tahun 1983 tentang Pajak Penghasilan

Undang-Undang Nomor 28 Tahun 2007 Tentang Ketentuan Umum Dan Tata Cara Perpajakan.

Undang-Undang Nomor 36 Tahun 2008 Tentang Pajak Penghasilan. 